Article

\title{
The Ground Zero Mosque Controversy: Implications for American Islam
}

\section{Liyakat Takim}

Sharjah Chair in Global Islam, McMaster University, University Hall, 116, 1280 Main Street West, Hamilton, Ontario, L8S 4K1, Canada; E-Mail: LTakim@McMaster.ca; Tel.: +1 (647) 8657863

Received: 29 March 2011; in revised form: 22 May 2011 / Accepted: 31 May 2011 /

Published: 7 June 2011

\begin{abstract}
The controversy surrounding the "ground zero mosque" is part of a larger debate about the place of Islam in U.S. public space. The controversy also reveals the ways in which the boundaries of American identity continue to be debated, often through struggles over who counts as a "real" American. It further demonstrates the extent to which Islam is figured as un-American and militant, and also the extent to which all Muslims are required to account for the actions of those who commit violence under the rubric of Islam. This paper will discuss how, due to the events of September 11, 2001, Muslims have engaged in a process of indigenizing American Islam. It will argue that the Park51 Islamic Community Center (or Ground Zero mosque) is a reflection of this indigenization process. It will go on to argue that projects such as the Ground Zero mosque which try to establish Islam as an important part of the American religious landscape and insist on the freedom of worship as stated in the U.S. constitution, illustrate the ideological battlefield over the place of Islam in the U.S. The paper will also examine the possible ramifications of building the Park51 Islamic Community Center including how this will shape the role that Islam plays in the socio-political lives America Muslims.
\end{abstract}

Keywords: Ground Zero; September 11; indigenization; American Islam; dialogue; American Islamic civic identity; Park 51 Islamic Community Center; Islamophobia; stereotype 


\section{Introduction}

In recent times, there has been much discussion in the American media on violence in Islam and on the place of Muslims in the American public square. Islam has been portrayed as violent and extremist and Muslim values as antithetical to American ones. It is therefore essential to discuss an issue that is of major concern to millions of people, especially in the post 9/11 era.

America has had a long history of intolerance and discrimination against minorities. Native Americans, Catholics, Jews, African Americans, the Japanese and others have, at one time or another, endured periods of discrimination. Events like the bombing of the World Trade Center and the Pentagon on September 11, 2001 have brought Islam and Muslims into the public focus. Recent discussions regarding establishing an Islamic community center near Ground Zero have further highlighted the debate on Islam in America.

Within this light, it is important to understand the history and instances of discrimination against Muslims in the United States. This paper will argue that projects such as the Ground Zero mosque (also called Park 51 Islamic Community Center) illustrate the ideological battlefield over the place of Islam in the U.S. The paper will also examine the possible ramifications of building the Park51 Islamic Community Center and will suggest some measures American Muslims can take to better their sociopolitical lives here.

Since early Muslim immigrants did not intend to stay in America, they did not invest in any religious or socio-political leadership that could offer an intellectual or political vision to the community. Rather, most of the early Muslim organizations were social, ethnic, or religious in nature. Societies like the Syrian and Lebanese American Federation of the Eastern States and the National Association of Syrian and Lebanese-American Organizations (formed in 1932) and the National Association of Federations catered primarily to the local Arab community. In 1952, under the leadership of Abdullah Ingram, immigrants from the Middle East formed the Federation of Islamic Associations in the United States (FIA). This was meant to be an umbrella body that would unite some twenty immigrant associations and provide for the social, cultural, and religious needs of the community [1]. Until the 1960s, there is little evidence to indicate that Muslims in America were politically engaged [2].

The Israeli-Palestinian conflict forced Muslims in America to reconsider their apolitical posture. American hostility towards the Arabs during the 1967 war and the general ignorance of the American public regarding the Middle East conflict led to the formation of the Association of Arab-American University Graduates (AAUG) in 1967. The AAUG was established by graduate students, professionals, university professors, lawyers, doctors, and veterans of the Organization of Arab Students (OAS) [3]. Most of the organizations in the 1970s were formed by American-Arabs who sought to establish a platform where the Arab-Muslim voice could be expressed. They also tried to have an input into the shaping of American foreign policy [4].

The 1980s and 1990s witnessed increased animosity towards Arabs and Muslims in the United States. In all probability, domestic groups like the conservative wing of the Republican Party, Christian fundamentalist groups, and the pro-Israel lobby were responsible for inciting and encouraging the anti-Islamic rhetoric. American hostility toward Islam and Muslims was also precipitated by various events overseas. These included: the six day war in 1967, the Yom Kippur war 
and subsequent oil embargo of 1973, the Islamic Revolution in Iran in 1979, the hostage crisis in Iran and Lebanon, PLO attacks against Israeli targets, the Rushdie affair of 1989, and the Gulf Wars. Such events precipitated measures that led to the targeting and profiling of Arabs and Muslims, along with a growing atmosphere of hostility towards Islam. As a matter of fact, a scheme known as Operation Boulder placed Arab-Americans under FBI surveillance in the early 1970s [5].

As Muslims continued to experience intimidation, discrimination, misunderstanding, and even hatred, they saw the need to educate Americans about Islam, correct some of the anti-Islamic images portrayed in the media, and protect the interests of the Muslim community. Hence, more Muslims organizations were established in the 1980s and 1990s. Their aim was not confined to educate Americans about the Arab-Israeli conflict. Rather, these institutions encouraged Muslims to address political and civil right issues that impacted the rights of the growing community.

Since the majority of the Muslims in America are Sunnis, most Muslim institutions were formed by them. These include institutes like the Federation of Islamic Associations in the United States (FIA) [6] the Muslim Student Association (MSA), the Islamic Society of North America (ISNA) the Islamic Circle of North America (ICNA), the Islamic Association of North America (IANA), the Muslim Public Affairs Council (MPAC), the American Muslim Alliance (AMA), the American Muslim Council (AMC) and the Council for American Islamic Relations (CAIR) [7].

These Muslim public affairs groups have been able to make the stereotyping of Muslims a matter of public debate and have documented many incidents of harassment, discrimination, and defamation against Muslims. They have also monitored and publicized discriminatory measures by government agencies and civic groups and have highlighted the distortion of Islam in the media.

\section{9/11 and Its Impact on the American Muslim Community}

The terrorist attacks of September 11, 2001 revived prejudices of Islam as a religion that promotes violence and of Muslims as an inherently militant people. Due to the attacks, Islam was projected in the media as violent and incompatible with American values and norms. In addition, the American global war on terror and the invasion of Iraq invigorated stereotypes and suspicions against Muslims, especially those of Middle Eastern origins.

Like other immigrants to America, Muslims have been defined as alien. This categorization has become more entrenched since the events of September 11, 2001 and is directed at Muslims who, more than any other immigrant group, are more vulnerable to discrimination and attacks. In fact, Muslims have encountered demonization and stereotypical images propagated, especially by the media.

Furthermore, the vitriolic attacks on Islam and the Qur'an by some Christian fundamentalists exacerbated the current conflict in America. They projected Islam as inherently violent and incompatible with Western norms. Such attacks tend to destroy rather than build bridges and engender hatred.

The effects of 9/11 on the Muslim community were far reaching and varied. The United States government implemented a wide range of domestic legislative, administrative, and judicial measures in the name of national security and the war on terror. Most of them were designed and have been carried out by the executive branch of government, with little a priori public discussion or debate. These measures included mass arrests, secret and indefinite detentions, prolonged detention of "material 
witnesses," closed hearings and use of secret evidence, government eavesdropping on attorney-client conversations, FBI home and work visits, wiretapping, seizures of property, removals of aliens on the basis of technical visa violations, and mandatory special registration.

Muslims have also had to endure the effects of the USA PATRIOT (Providing Appropriate Tools Required to Intercept and Obstruct Terrorism) Act of October 24, 2001. The act sanctions the monitoring of individuals, organizations, and institutions without notification. Its provisions have been protested by American Civil Liberties Union. Several Arab and Muslim organizations have recently sued the American government insisting that the act is unconstitutional. In 2007, disclosures of secret wiretapping of suspected terrorists and the federal government's admission that, in search of a terrorist nuclear bomb, it has run a far-reaching, top secret program to monitor radiation levels at over a hundred Muslim homes, businesses, and mosques in the capital region and in other areas, have all augmented Muslim concern regarding their civil rights. In numerous cases, the monitoring required investigators to go on to the property under surveillance, although no search warrants or court orders were ever obtained. During the process, the PATRIOT act has also lifted all legal protection of liberty for Muslims and Arabs in America [8]. Due to its efforts to safeguard the interests of the Muslim community, the Council on American-Islamic Relations (CAIR) has emerged, in the eyes of many Muslims, as the Muslim equivalent of the Jewish Defense League.

Since 9/11, Islamophobia and hatred towards Muslims have become legitimized and acceptable byproducts of national media and American culture. This has left many migrants and second generation Muslims with a sense of alienation and marginalization. Furthermore, the verbal attacks on Islam and the Qur'an by some Christian fundamentalist groups have engendered more hatred against American Muslims. Franklin Graham labeled Islam as a "very evil and wicked religion" whereas Jerry Vines, a former president of the Southern Baptist Convention, said the Prophet Muhammad was a "demonobsessed pedophile" [9]. On public television, Jerry Falwell called the Prophet a pedophile and a terrorist [10]. Rhetoric such as these further amplified the prejudices and stereotypical images of Islam and Muslims.

Prejudices such as those described above tend to exaggerate characteristics of a group that is different from other groups. Stereotyping a group also means that "the moderate other" that lies within "the enemy other" is hidden since the whole group is clustered in a particular compartment. In the process, the views of other Muslims are overlooked or ignored. Thus, the majority of the Muslims who are opposed to violence receive scant attention in the media since their voices are silenced by the violence of the minority Muslim other.

A study by the Pew Research Center showed that, of over 1,000 Muslim Americans surveyed, about half indicated that their life has become more difficult after September 11 [11]. Furthermore, a quarter say they have been the victims of discrimination, and 54 percent feel Muslims are singled out for extra-government surveillance [12]. A Gallup poll in the summer of 2006 of more than 1,000 Americans showed that 39 percent were in favor of requiring Muslims in the United States, including American citizens, to carry special identification.

Legal and political measures are augmented by continued public backlash - hate crimes, hate speech and job discrimination - sensationalized media portrayals of Muslims, and strong antiMuslim/anti-Islamic rhetoric from the political right. Not only do Muslims feel vulnerable in America they also feel as if they are being continuously watched and under the constant threat of arrest [13]. 


\section{The Ground Zero Center Project and Its Implications for American Islam}

The above discussion was necessary to show the kinds of prejudices against and stereotyping of Islam and Muslims before the Ground Zero controversy arose in 2010. The project was originally called Cordoba House, then renamed Park51, referring to the street address on Park Place. The Cordoba House project is a planned 13-story community center to be located two blocks from the World Trade Center site in Lower Manhattan. It will contain a Muslim prayer space that has been referred to as the "Ground Zero mosque", though it is not intended to be a mosque nor is it to be located at Ground Zero. In fact, the term "Ground Zero mosque," which was coined by right-wing activist Pamela Geller, is a misnomer since it depicts the distorted impression that the center is to be constructed on the actual site of the 9/11 tragedy and former World Trade Center.

It is also important to note that the center is not to be built along the lines of a traditional Islamic center or mosque. The plans for the center include a 500-seat auditorium, a theatre, a performing arts center, a fitness center, a swimming pool, a basketball court, a childcare area, a bookstore, a culinary school, an art studio, a food court, and a memorial to the victims of the September 11 attacks. The prayer space for the Muslim community is planned to occupy two floors of the thirteen story building.

Thus the vision of the organizers is to build a community center with Islamic, interfaith and secular programming. In the words of the project's organizers it is intended to be "a platform for multi-faith dialogue. It will strive to promote inter-community peace, tolerance and understanding locally in New York City, nationally in America, and globally" [14]. Imam Faisal Abdur Rauf, who is spearheading the project, has further stated that the community center will be open to people of all faiths and seeks to build bridges and promote peace. It is hoped that the community center would provide, a "cultural nexus" for New Yorkers to come together for education, performances, sports and person-to-person interaction.

\section{Controversy Surrounding the Project}

The proposal continues to trigger a nationwide controversy [15], with opponents of the project objecting to its proximity to the site of the September 11 attacks, its scale, or sources of funding [16]. A group of the victims' relatives, 9/11 Families for a Safe and Strong America, called the proposal "a gross insult to the memory of those who were killed on that terrible day" [17].

Opposition to the project is also discernible in some of the polls conducted soon after the proposal to build the center was announced. The majority of Americans were opposed to the mosque/Islamic center, The New York Times reported in July 2010 [18]. By a margin of 54\%-20\%, American adults were opposed to a mosque being built near Ground Zero, a national Rasmussen Reports poll found that month [19]. Furthermore, according to an August 10-11 Fox News poll, 64\% of Americans [a majority of each of Democrats (56-38\%), Republicans (76-17\%), and Independents (53-41\%)] thought it would be wrong to build a mosque and Islamic cultural center so close to Ground Zero [17].

However, some relatives of those who perished on 9/11 expressed support for the project. Orlando Rodriguez and Phyllis Schaefer Rodriguez, whose son died in the attack, say they "support the building of the Islamic community center in lower Manhattan" and "feel that it would honor our son and other victims" [20]. Ted Olson, former Solicitor General in the George W. Bush administration, 
whose wife, television commentator Barbara Olson, died in the plane that crashed into the Pentagon, has expressed support for the rights of the Park51 organizers to construct the new site. In remarks on MSNBC, Olson said "we don't want to turn an act of hate against us by extremists into an act of intolerance for people of religious faith" [21]. Prominent figures such as President Obama and New York Mayor Bloomberg have also supported the project.

The controversy reflects one of many incidents in the last decade that signal how Islam is perceived as un-American and even anti-American. The controversy surrounding the project has had resounding effects all over America. Plans to build mosques have led to a wave of hate crimes against Muslim individuals, mosques, and Muslim-owned businesses around the country. In California, many community members resisted the Islamic Center included in Temecula Valley's expansion plans; the pastor of the neighboring church expressed concern over Islam's extreme agenda of expansion. The fact that other mosque-construction projects across the country from Brooklyn and Staten Island in New York to Dayton in Ohio have also encountered similar opposition points to something more to than just outrage over the proposed mosque's proximity to ground zero. The controversy over building mosques in the U.S. also suggests that many Americans equate mosques with the radicalization of American Muslims, even though there is no data to support such an assumption.

In December 2010, a suspect was apprehended in the compounds of the Islamic Center of America, in Dearborn, Michigan. He was carrying firearms and intended to destroy the mosque. The incident suggests that some Americans are being radicalized against Islam, turning the argument on the growing Muslim radicalization on its head. Muslims argue that it is Americans, not just Muslims who are being radicalized.

Most notoriously, a church in Gainesville, Florida planned to commemorate the ninth anniversary of the September 11 attacks by hosting a Qur'an burning ceremony. Pastor Terry Jones of the Dove World Outreach Center's "International Burn a Koran Day" told CNN, "We believe that Islam is of the devil, that it is causing billions of people to go to hell, it is a deceptive religion, it is a violent religion and that is proven many, many times" [22].

The subtle message coming from such Christian fundamentalists or those who have maligned Islam and Muslims is that Muslims need to reform so they can become like "us Americans". They should endorse and reflect American values and social choices. For many such Americans, Muslims who do not observe Islam or are invisible are the good Muslims.

This polarization of good and bad Muslim puts those Muslims who agree with American values and foreign policies as the "good Muslims" whereas the rest are cast as villains. As Omid Safi correctly notes, this dichotomy ignores a third group of Muslims: those who want to neither destroy the World nor acquiesce to the wishes of the Empire, but rather seek to redeem the World by speaking truth to power. This group speaks out of the love of God and cries out for the suffering of humanity, defiantly and prophetically standing up for justice and liberation [23].

The controversy over Muslim identity in America was further exacerbated by the congressional hearings in March 2011. The hearings were headed by congressman Peter King. Speakers at the hearings were carefully chosen to enhance the "radical American Islam" syndrome. Gruesome stories were related at the hearings by those whose children had been radicalized. The hearings were largely skewed since the voices of Muslims who have spoken against terrorism and cooperated with law enforcement agencies to combat radicalization among the Muslim youth were missing. 
As we approach the tenth anniversary of September 11, we are seeing more rather than less incidents of Islamophobia. Muslims feel that after September 11, 2001, Islamophobia was expressed by a few right-wingers. In 2011, by conducting the hearings, some congressmen have amplified the anti-Muslim rhetoric. Indeed, many states - from Georgia to Missouri to New Mexico - are considering bans on the possible implementation of the Shari'a, or Islamic law in their states.

The fact that the project has created such a major controversy suggests that the Ground Zero mosque is part of a larger debate about the place of minorities (and in particular Muslims) in U.S. public life. The Ground Zero controversy also exposes many underlying assumptions about religion in the public space and politics, particularly in the case of American Muslims, who are given the option of being either politically suspect or socially and religiously invisible, thereby acquiescing in the face of much prejudice and discrimination.

The preceding discussion illustrates the ideological battlefield over the place of Islam in the U.S. Without personal direct knowledge of Islam and Muslims, many people have no effective way to counter the skewed perspective. It is this continuing cycle of broad, stereotypical representation and hindered local intergroup contact that allows an association between Muslims and terrorism to become taken for granted in American public life [24].

The prejudices, hatred, and attacks against Muslims and Islam ignore the multiplicity of voices and nuances prevalent within Islam. They also ignore that fact that Muslim communities are multivocal and hold diverse views. Since 9/11, in the media and in the eyes of many Americans, all distinctions between Muslims have been obliterated. Distinctions between Shi'is and Sunnis, moderate or conservative, Christian or Muslim Arabs have been effaced. Instead, all Muslims and Arabs have been grouped together as the 'enemy other.' Muslims have had to apologize for acts they did not commit, and to condemn acts that they never condoned. They have been found guilty by religious association, drawn into a discourse on terrorism and associated with a radicalized fringe group (al-Qa'ida) which has been condemned by the majority of their leaders.

Projects such as the Ground Zero mosque will become more consequential as Muslims endeavour to make Islam an essential feature of the American religious landscape. Such projects further illustrate how Muslims continue to struggle in the ideological battlefield over the place of Islam in the U.S. and in asserting their identity as American Muslims.

It should be remembered that America is multi-religious by design and not because of an accident of history or immigration. The "disestablishment" principle commonly referred to as the separation of church and state detaches civil authority from the sphere of religious activity in a way that puts restraints upon the former. Such measures were advocated by religious minorities such as the Quakers, who wanted to protect their religious life from the control of majority denominations. What often gets obscured in the rhetoric against Islam and Muslims is that the American constitution has guaranteed protection and freedom of worship to all religious communities. Banning the Shari'a could mean that Muslims could be technically arrested for worshipping in a public arena.

\section{What Can Be Done?}

Increasingly, Muslims have become aware that they cannot afford to live in impregnable fortresses and that living in a pluralistic milieu requires an active engagement with the "other." They need to go 
beyond the history of hostility, caricature, and power struggles that have characterized relations between Muslims and non-Muslims in the past. The struggle for Muslims in America is not only to coexist with the other, but also to make themselves comprehensible in the American milieu, to demythify and de-code Islam and to challenge the negative characterization of Islam. Muslims need to also realize that, due to the activities of terrorists, both their Islamic identity and American citizenship are at stake.

In the post 9/11 era, the Muslim community has acknowledged that the silent majority syndrome has to end simply because Muslim acquiescence has encouraged an extremist expression of Islam. It is the extremists who have spoken on behalf of Islam as their acts of violence have drowned out the silent voices of the Muslim majority. Thus, many Muslims have felt the need to integrate themselves into mainstream American society so as to make their voices heard. This integration of American Islam represents a silent revolution that many Muslims have been engaged in since September 11, 2001 [25].

As the second and third generations of Muslims have come to see America as their permanent home, they have appropriated distinctly American values and outlook. Muslims all over America have opted for voluntary social activism and to identify with mainstream American culture, develop a sense of patriotism leading to a greater politicization of the community and a sense of American national consciousness. This is their way to counter marginality, Islamophobia, and social exclusion.

An important measure that Muslims need to adopt is to indigenize American Islam. Indigenization of American Islam is the process of identifying, understanding, and relating to the culture, heritage, and the history of America. Indigenization also means carving out a space for oneself in American society, being more appreciative of American values while remaining authentic to Islam. An essential element of the indigenization of American Islam is Muslims' identification with American culture and values, and their distancing themselves from an 'old world' mentality. Indigenization also means viewing American secular culture as a challenge to be comprehended and negotiated rather than a threat to be confronted, for the latter approach can breed a culture of negative isolation and fear of the 'other'.

Indigenization of American Islam does not mean either the Arabization or Indianization of Islam; rather, it means interpreting its central messages so that it is suitable to American Muslim identity without sacrificing its doctrinal integrity. Thus, it is correct to state that indigenization is an internal process, one that cannot be imposed from abroad [26]. It has to be formulated, articulated, and expressed by those Muslims who are familiar with the American milieu and culture. Indigenization also means that American Muslims have to increasingly express themselves through a properly articulated intellectual discourse, so that they can be both physically and intellectually visible.

The process of the indigenization of American Islam is intertwined with the construction of a distinctly American Islamic civic identity. The community has to embark on coalition building with human rights, religious rights, and civil rights groups. In recent times, Muslim groups have been involved in various social programs like food drives and have sought to help homeless Americans.

Indigenization also means that rather than focusing on American foreign policy, Muslims have to now to concentrate more on reconstituting their identity as American Muslims. In all probability, this is because as the second generation of Muslims in America identifies with and assimilates in American culture, it develops a sense of patriotism leading to a greater politicization of the community and a sense of national consciousness. 
During the last decade, Muslim public affairs' groups like CAIR (Council of American Islamic Relations) have been able to make the stereotyping of Muslims a matter of public debate and have documented many incidents of harassment, discrimination, and defamation against Muslims. They have also monitored and publicized discriminatory measures by government agencies and civic groups and have highlighted the distortion of Islam in the media.

Hence, the process of indigenization has begun. By convening seminars, publishing articles in magazines and Islamic newsletters, delivering lectures at various conventions and workshops, Islamic organizations have begun to alter the way Muslims think about the United States and about themselves. As the 'old world' or 'back-home' mentality gradually fades, as it largely did in the mid1980s and early 1990s, organizations are shifting Muslim political and civil discourses in the United States to how Muslims can interact with Americans, while maintaining their own distinctive identity. Muslims are also grappling with issues like the scope and nature of Muslim participation in the American public square. The vision is now on repositioning Islam as an element of American national interest and not as a threat to it.

American Muslims also have come to the realization that civic engagement may be the most powerful way to fulfill their political aspirations in America. Vital issues, such as civil rights, immigration, foreign policy, education, and social and economic justice, can be positively affected by political lobbying. Political power can be only be enhanced by the politics of engagement between American Muslims and other players in the political system. It is to their advantage to seek ways of influencing governance (especially with regards to policy formation), as well as American foreign and domestic policies [27].

\section{The Role of Inter-faith Dialogue}

Another important way to reduce the distorted images many have about Islam is to engage in interfaith dialogue. Dialogue is important as it provides a platform for each group to define itself. Each group is able to better express what it believes, and, in the process, to understand more deeply the meaning of what it means to be committed to a particular faith tradition. The process of selfdefinition requires that each group express itself based on its own terms, and for the partner in dialogue to accept and respect that self-definition. In the process, our preconceived notions of the other are challenged and often dramatically altered. This is the first step to moving beyond the stereotypes and misrepresentations of the past [28]. It is improper for Muslims, for example, to assume that their oftendistorted images and understandings of Christianity reflect how Christians themselves understand elements in their own faith traditions. An ability to change one's views and perceptions about the other is an important component if interactions between peoples of different religious backgrounds is to lead to a more peaceful co-existence between them. Interfaith dialogue ought to enhance sensitivities between faith groups, not produce doctrinal agreements. As the Parliament of the World's Religions affirmed in Chicago in 1993, "Earth cannot be changed for the better unless the consciousness of the individuals is changed first [29].

Dialogue must progress beyond negating misconceptions and understanding the beliefs and praxis of others. Dialogue is also interwoven with fundamentally understanding what it means to be invested in a particular religious tradition. It must try to enter into the heart of the partner in dialogue. Muslims, 
for example, must attempt to understand what it means for Christians to affirm Christ as the Savior and the significant role that the doctrine of the Trinity plays in Christianity, just as Christians need to comprehend the pivotal role of the Prophet and the Qur'an in the lives of Muslims.

As dialogue provides access to understanding others' self-definition, it challenges us grow in our own faith through the experience of the other, and to re-evaluate how we have viewed the other. It also necessitates a shift in paradigm, asking us to embrace those whom we have previously excluded or demonized. The challenge for both Muslims and non-Muslims when they converse is to seek opportunities for interpretations that can make a community see the enemy in a new way. It is essential that we move away from defining ourselves over and above an enemy "other." This is an important measure to establish a peaceful relationship [30]. In this sense, I believe, we need to go beyond merely tolerating the other [31]. More than ever, there is the need to embrace the other [32]. This suggests a different function of dialogue, one that can bring the hearts, rather than just the minds, of the people together.

A major obstacle to engaging with the other is juxtaposing one's ideals and the other's realities. Viewed in this context, violence perpetrated by one side is often contrasted with the ideals of peace and love of the other. A more appropriate basis for comparison is to compare ideals with ideals, or realities with realities, for example, to compare one side's realities with the realities of those with whom one is in dialogue. As such, both sides often discover injustices inflicted by the other, and both sides often discover that perhaps, in the name of religion, each has committed atrocious acts against the other. Indeed, disputes often arise when one side believes that it is solely the victim and refuses to accept any role in the conflict and wrongdoing. Dialogue provides challenges and opportunities for both sides (i.e., Muslims and non-Muslims) to acknowledge that each has inflicted and suffered much pain. For this to occur, dialogue needs to transcend mere understanding of the other; it also has to provide the platform for one side to empathize with the other. As a friend commented, "By internalizing the other's pain, dialogue enables me to view the other as a brother."

\section{Conclusions}

In the United States, pluralism and diversity have often evoked more conflict than cooperation. Encouraging self-expression of different ethnic and racial identities has bred more - not less insularity, intolerance, and/or prejudice. Arguably, people's diverse histories and cultures, instead of being an occasion for broadening the resources of society at large and for seeking solutions to common human problems, have become an occasion to blame, censure, exclude and demand special rights.

Contemporary American Muslims are confronted with stereotypical images constructed through the media and the emerging political reality that often challenges the applicability of those images. The tension between the negative images of Islam and Muslims on the one hand and the reality of American Islam on the other can be resolved only through an integration of Muslims into American society on the one hand and an effort to educate Americans about the reality of Islam and Muslim life on the other. Peaceful coexistence is only possible when one no longer sees a group as an abstract 'other' but rather as a particular human community with its specific traditions, values and norms. Ultimately, peaceful relations between human beings are grounded on a universal order based upon egalitarianism, justice, and a concern for the moral and social well being of all citizens. 
The controversy surrounding the "Ground Zero mosque" is part of a larger debate about the place of Islam in U.S. public life. It reveals the struggle over who measures as a "real" American. It further demonstrates the extent to which, in the eyes of many Americans, Islam is figured as un-American and terroristic, and also the extent to which all Muslims are held responsible for the actions of those few who commit violence under the rubric of Islam.

It is important to understand the role of Muslims in weaving the religious as well as social tapestry of America and to see several gaps - between religion and culture, the gap between media and the reality of Islam, and the lacuna between religious loyalty and national identity. With time, these gaps will be filled. It is here that the challenge for the next generation of Muslims lies.

\section{References and Notes}

1. Haddad, Y.Y. American Foreign Policy in the Middle East and Its Impact on the Identity of Arab Muslims in the United States. In The Muslims of America; Haddad, Y.Y., Ed.; Oxford University Press: New York, NY, USA, 1991; pp. 225-226.

2. Haddad, Y.Y. Not Quite American? The Shaping of Arab and Muslim Identity in the United States; Baylor University Press: Waco, TX, USA, 2004; p. 17.

3. Haddad, Y.Y. Not Quite American? The Shaping of Arab and Muslim Identity, p. 20.

4. Haddad, Y.Y. Not Quite American? The Shaping of Arab and Muslim Identity, pp. 49-50.

5 Haddad, Y.Y. American Foreign Policy in the Middle East. In The Muslims of America; Haddad, Y.Y., Ed; Oxford University Press: New York, NY, USA, 1991; p. 220.

6. On the early history of the FIA see Ahmed, G.M. Muslim Organizations in the United States. In The Muslims of America; Haddad, Y.Y., Ed.; Oxford University Press: New York, NY, USA, 1991; pp. 12-14.

7. For a list of American Muslim organizations see Cesari, J. When Islam and Democracy Meet: Muslims in Europe and in the United States; Palgrave: New York, NY, USA, 2004; pp. 185.

8. Haddad, Y.Y. Not Quite American? Baylor University Press: Waco, TX, USA, 2004; p. 42.

9. Hussain, A. Muslims, Pluralism, and Interfaith Dialogue. In Progressive Muslims: On Justice, Gender, and Pluralism; Safi, O., Ed.; Oneworld: Oxford, UK, 2003; p. 261.

10. Abdo, G. Mecca and Main Street: Muslim Life in America after 9/11; Oxford University Press: New York, NY, USA, 2006; p. 85.

11. Pew Research Center. Muslim Americans: Middle Class and Mostly Mainstream. http://pewresearch.org/pubs/483/muslim-americans (accessed on 21 March 2011).

12. Pew Research Center. Muslim Americans: Middle Class and Mostly Mainstream. http://pewresearch.org/pubs/483/muslim-americans. [retrieved on 21 March 2011].

13. Cesari, J. When Islam and Democracy Meet; Palgrave: New York, NY, USA, 2004; p. 41.

14. http://www.newshounds.us/2010/10/20/can_we_expect_oreilly_to_grab_his_saw_and_hammer_ to_help_build_the_ground_zero_mosque.php (accessed on 21 March 2011).

15. Sanchez, R. Despite Protests, Mosque Plan Near 9/11 Site Wins Key Vote. ABC News, 26 May $2010 \quad$ Available online: http://abcnews.go.com/US/mosque-plan-clears-hurdleprotests/story?id=10747570 (accessed on 21 March 2011). 
16. Hernandez, J.C. Mosque Near Ground Zero Clears Key Hurdle. The New York Times, 3 August 2010. Available online: http://cityroom.blogs.nytimes.com/2010/08/03/mosque-near-ground-zeroclears-key-hurdle/ (accessed on 21 March 2011).

17 Park51. http://en.wikipedia.org/wiki/Park51 (accessed on 21 March 2011).

18. Barbaro, M. Debate Heats Up About Mosque Near Ground Zero. The New York Times, 30 July 2010, Available online: http://community.nytimes.com/comments/www.nytimes.com/2010/07/31/ nyregion/31 mosque.html (accessed on 21 March 2011).

19. Rasmussen Reports.com. Rasmussen Poll: Most Oppose Mosque Near Ground Zero. 22 July 2010. http://www.myfoxny.com/dpps/news/local_news/manhattan/Rasmussen-Poll-MostOppose-Mosque-Near-Ground-Zero_8789239 (accessed on 21 March 2011).

20. The AmLaw Daily. Ted Olson Joins NYC Mosque Debate author= Brian Baxter. http://amlawdaily.typepad.com/amlawdaily/2010/08/tedolsonmosque.html (accessed on 21 March 2011).

21. http://en.wikipedia.org/wiki/Park51\#cite_note-nytimes4-85 (accessed on 21 March 2011).

22. The "Ground Zero Mosque" Controversy and "Post-Race" Racism, Evelyn Alsultany, http://hemisphericinstitute.org/devotion/2010/10/the-\%E2\%80\%9Cground-zero-mosque $\%$ E2\%80 $\% 9 \mathrm{D}$-controversy-and-\%E2\%80\%9Cpost-race $\% \mathrm{E} 2 \% 80 \% 9 \mathrm{D}$-racism/ (accessed on 21 March 2011).

23. Omid, S. Good Sufi, Bad Muslims, University of Chicago's Martin Marty Center Journal, http://divinity.uchicago.edu/martycenter/publications/sightings/archive_2011/0127.shtml January 2011 (accessed on 21 March 2011).

24. Mohamed, B.; O’Brien, J. Ground Zero of Misunderstanding. Cultural Reviews. Contexts 2010, No. 1, 62-64.

25. Takim, L. From Conversion to Conversation: Interfaith Dialogue in Post-911 America. The Muslim World 2004, 3, 343-355.

26. On the difference between indigenization and assimilation, see Sherman, J. Islam and the Blackamerican: Looking Toward the Third Resurrection; Oxford University Press: New York, NY, USA, 2005; p. 169.

27. See also Mazrui, A. Muslims between the Jewish Example and the Black Experience: American Policy Implications. In Muslims' Place in the American Public Square; Bukhari, Z.H., Nyang S., Ahmad, M., Esposito, J.L., Eds.; AltaMira Press: Walnut Creek, CA, USA, 2004; p. 127.

28. For rules on dialogue, see Bryant, D. Overcoming History: On the Possibilities of MuslimChristian Dialogue. In Muslim-Christian Dialogue, Bryant, D., Ali, S.A., Eds.; Paragon House: St. Paul, MN, USA, 1998; p. 34.

29. Chappell, D. Interreligious Dialogue, Globalization, and Human Rights: Buddhist Reflections on Interdependence and the Declaration. In Human Rights and Responsibilities in the World Religions; Runzo, J., Martin, N., Sharma, A., Eds.; Oneworld: Oxford, UK, 2003; p. 191.

30. See the example cited by Gopin, M. Holy War, Holy Peace: How Religion Can Bring Peace to the Middle East; Oxford University Press: Oxford, UK, 2002; p. 44.

31. The root of the term tolerance comes from the medieval toxicology and pharmacology, marking how much poison a body could tolerate before it would succumb to death. See Safi, O. 
Introduction: The Times are A-Changing; - A Muslim Quest for Justice, Gender Equality, and Pluralism. In Progessive Muslims; Safi, O., Ed.; Oneworld: Oxford, UK, 2003; p. 24.

32. Volf, M. Exclusion and Embrace, A Theological Exploration of Identity, Otherness and Reconciliation; Abingdon: Nashville, TN, USA, 1996.

(C) 2011 by the authors; licensee MDPI, Basel, Switzerland. This article is an open access article distributed under the terms and conditions of the Creative Commons Attribution license (http://creativecommons.org/licenses/by/3.0/). 